\title{
SUBMARINE KARST OF CROATIA - EVIDENCE OF FORMER LOWER SEA LEVELS
}

\author{
PODMORSKI KRAS NA HRVAŠKEM - \\ DOKAZ O NEKDANJI NIŽJI MORSKI GLADINI
}

MAŠA SURIĆ ${ }^{1}$

${ }^{1}$ Dept. of Geography, Faculty of Philosophy in Zadar, Ul. dr. F. Tuđmana bb, HR-23000 ZADAR, CROATIA

Prejeto / received: 15. 7. 2002 


\section{Maša Surić: Podmorski kras na Hrvaškem - dokaz o nekdanji nižji morski gladini}

Med zadnjo, to je pleistocensko-holocensko transgresijo, je naraščajoča morska gladina zalila velike dele dinarskega krasa. Ker porečja rek na vzhodni jadranski obali sestavljajo pretežno karbonatne kamnine, te reke prenašajo le okoli $20 \%$ sedimentov v obliki suspenza, vse ostalo pa kot raztopljeni tovor. Zaradi tega je pod morsko gladino še vedno mogoče ugotavljati značilne kraške oblike, kot so škraplje, vrtače, polja, jame in brezna, kot tudi rečne doline in soteske. Poleg teh preprostih potopljenih oblik so zaradi dvigajoče se gladine nastale tudi nove: podmorski izviri imenovani vrulje, zaslanjeni obalni izviri in morska jezera. Najpomembnejši dokazi o nekdanjem kopnem okolju so kapniki v potopljenih jamah in lehnjak v potopljenih nekdanjih rekah. Te oboje je mogoče uporabiti za ugotavljanje nekdanje nižje morske gladine.

Ključne besede: podmorski kras, dvig morske gladine, Jadransko morje, Hrvaška.

\section{Abstract}

UDC: $551.44(26.03)(497.5)$

\section{Maša Surić: Submarine karst of Croatia - evidence of former lower sea levels}

During the last, Late Pleistocene-Holocene transgression, rising sea flooded a vast part of the Dinaric karst. Due to prevalence of carbonate rocks in the drainage area of most of the rivers on Eastern Adriatic coast, those rivers carry only approximately $20 \%$ of particulates as suspended matter and the rest is dissolved. Consequently, many typical karst features such as karrens, dolines, poljes, caves, pits and river valleys and canyons as well, presently under the sea, can still be recognized. Beside these simply drowned features, some new ones were formed by the sea level rise. Those are submarine springs, so called vruljas, brackish coastal springs and marine lakes. The most significant evidences of former subaerial conditions are speleothems in submerged caves and calc tufa deposits of drowned paleo rivers. Both of them could be used for determination of the former low sea level stands.

Key words: submarine karst, sea level rise, Adriatic Sea, Croatia. 


\section{INTRODUCTION}

The considerable part of the Croatian Dinaric karst is now under the sea due to the last Late Pleistocene-Holocene transgression. Some $18 \mathrm{ky} \mathrm{ago,} \mathrm{at} \mathrm{the} \mathrm{maximum} \mathrm{of} \mathrm{Würm} \mathrm{glaciation,} \mathrm{the}$ sea level was cca $125 \pm 5 \mathrm{~m}$ lower than today (Fairbanks 1989). Consequently, karstification processes affected the carbonate bedrock downward to the absolute erosional basis - the sea level. Today, in spite of thousands of years in the sedimentary environment, all types of karst features (karrens, dolines, poljes, caves, pits, river valleys and canyons, etc.) are still recognizable on the sea bottom, due to the very slow sedimentation rate thanks to the prevalence of easily soluble carbonate rocks in the drainage area of most of the rivers on Eastern Adriatic coast. Namely, only

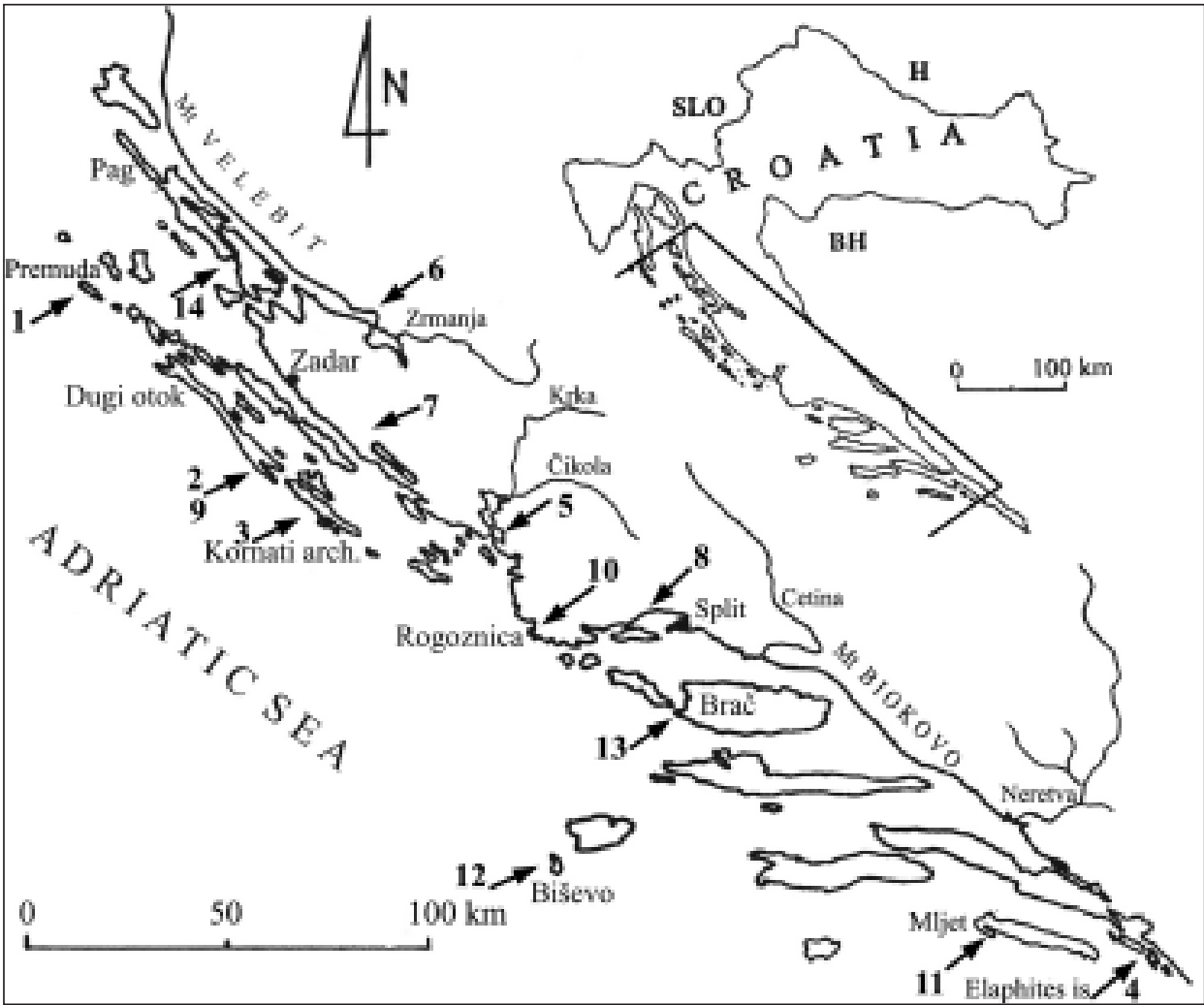

Fig. 1: Some localities with characteristic coastal and submarine karst features: steep tectonical coasts of Premuda Island (1), Dugi otok Island (2), Kornati archipelago (3) and Elaphites Islands (4); submerged canyon of Paleo Krka river (5); submarine spring Vrulja Zečica (6); coastal spring Stabanj (7); hydrological system: vruljas in Kaštela Bay - brackish coastal spring Pantan - intermittent brackish spring Slanac (8); marine lakes: Mir (9), Zmajevo oko (10), Veliko Jezero and Malo jezero (11); submarine speleological objects: cave Modra Spilja (12), Pit in Lučice Bay (13) and Cave in Tihovac Bay (14). 
approximately $20 \%$ of river-borne material is suspended and the rest is dissolved, so the sea bottom is just partly covered with recent sediments. On the contrary, the western Adriatic intensively fills with suspended material carried by river Po and other Apennine rivers, rapidly covering existing features (Correggiari et al. 1996).

\section{SOME EXAMPLES OF SUBMERGED KARST FEATURES}

A major part of the Eastern Adriatic coast is rocky with karren forms continuing under the sea. Karrens are slightly reshaped, somewhat sharper, because of the processes of bioerosion, and not because of corrosion by the sea water, since is supersaturated by $\mathrm{CaCO}_{3}$ to the depths of 500 m (Kennett 1982). A minor part of coast is gravelly, mostly on the contact of the sea with flysch deposits and sandy in the areas of accumulations of Pleistocene aeolian sands. The island of Susak, looking like typical sandy islet, is, in fact, such accumulation of loess and loess-like sediments deposited on the karstified carbonate base (Bognar \& Zámbó 1992). Similar compositions are also on Mljet island (Bognar et al. 1992) and on the island of Lopud (Elaphites island) (Magaš et al. 2001).

Another type of the coast are cliff-like forms which can be found on the western sides of some islands (Premuda, Dugi otok, Kornati archipelago, Elaphites islands, Cres, Krk) (Fig. 1). Although they look like cliffs, their genesis is not the result of abrasion but of the vertical land movements along the extensive longitudinal faults (Benac, 1989; Bognar \& Grizelj 1995). The longest and most expressed is Dugi otok fault, over $250 \mathrm{~km}$ long, spreading in Dinaric direction (NW-ES) along the outer sides of Croatian islands, from the Istrian peninsula to the island of Brač. Steep, practically vertical coast is, in fact, a fault plane reaching the depths of $100 \mathrm{~m}$ under the sea level and heights up to $200 \mathrm{~m}$ a.s.l., partly reshaped by abrasion (Prostorni plan 1990).

Fault plane of the other important fault Vis-Lastovo-Dubrovnik, oblique SW coasts of Elaphites islands. At the intersections of transversal fractures and this longitudinal fault, numerous dolines were formed. Vertical dislocation of the fault limbs opened the whole profile of dolines and exposed the already damaged rock mass to the abrasional forces of the waves. Now, they are in a form of small coves (local term "biga") (Magaš et al. 2001).

During the cold periods of the Pleistocene, karstic rivers Raša, Zrmanja, Krka, Cetina and Neretva cut their canyons downward to the former lower erosional basis, theoretically to $-125 \mathrm{~m}$. Now, canyons of rivers Raša and Neretva are partly filled since those rivers carry considerable amount of suspended matter from their non-karstic source zones. But, the canyon of paleo-river Krka is still recognizable to a depth of $100 \mathrm{~m}$ between Zlarin Island and mainland (Roglić 1967, Juračić 1992), as well as Zrmanja River canyon in Novsko ždrilo straits and in the Velebit Channel.

Besides canyons themselves, the evidences of lower sea level stands and karstic environment are calc-tufa deposits. Tufa deposits are formed by calcite precipitation from fresh water supersaturated with $\mathrm{CaCO}_{3}$ by the consumption of $\mathrm{CO}_{2}$ by plants within karstic rivers (Horvatinčić et al. 2000). In the canyon of Paleo-Krka, there are still remnants of four tufa barriers not older than 9000 years, indicating paleoenvironmental settings: subaerial conditions, favourable climate and reduced erosion (Roglić 1967).

Submarine springs - vruljas, are rather common features along the Eastern Adriatic coast, even along the islands (Alfirević 1969), formed by submerging of coastal karstic springs. Most 
remarkable ones are located in the areas where intensively karstified mountain ranges (Mt Velebit, Mt Biokovo) rise directly from the sea, canalising groundwater from the hinterland. Identically as with springs on the land, very often vruljas appear on the contacts of permeable Cretaceous carbonates and impermeable Eocene flysch e.g. under Biokovo mountain and in Kaštela Bay (Milanović 1979; Fritz 1994; Fritz \& Bahun 1997). Submarine discharge is most intensive during winter and spring; thus some submarine springs are active only during that periods. Anyway, most submarine groundwater discharge occurs as disperse seepage on the sea bottom (Milanović 1979).

Corrosional processes of karstification undoubtedly cease by the sea water flooding, but the erosion can go on even under the sea, precisely through the major channels of the submarine springs with abundant discharge. An example is vrulja Zečica under Mt Velebit (Fig. 2) in which pebbles and cobbles originating from Mt Velebit can be found (Bakran-Petricioli \& Petricioli, 1999).

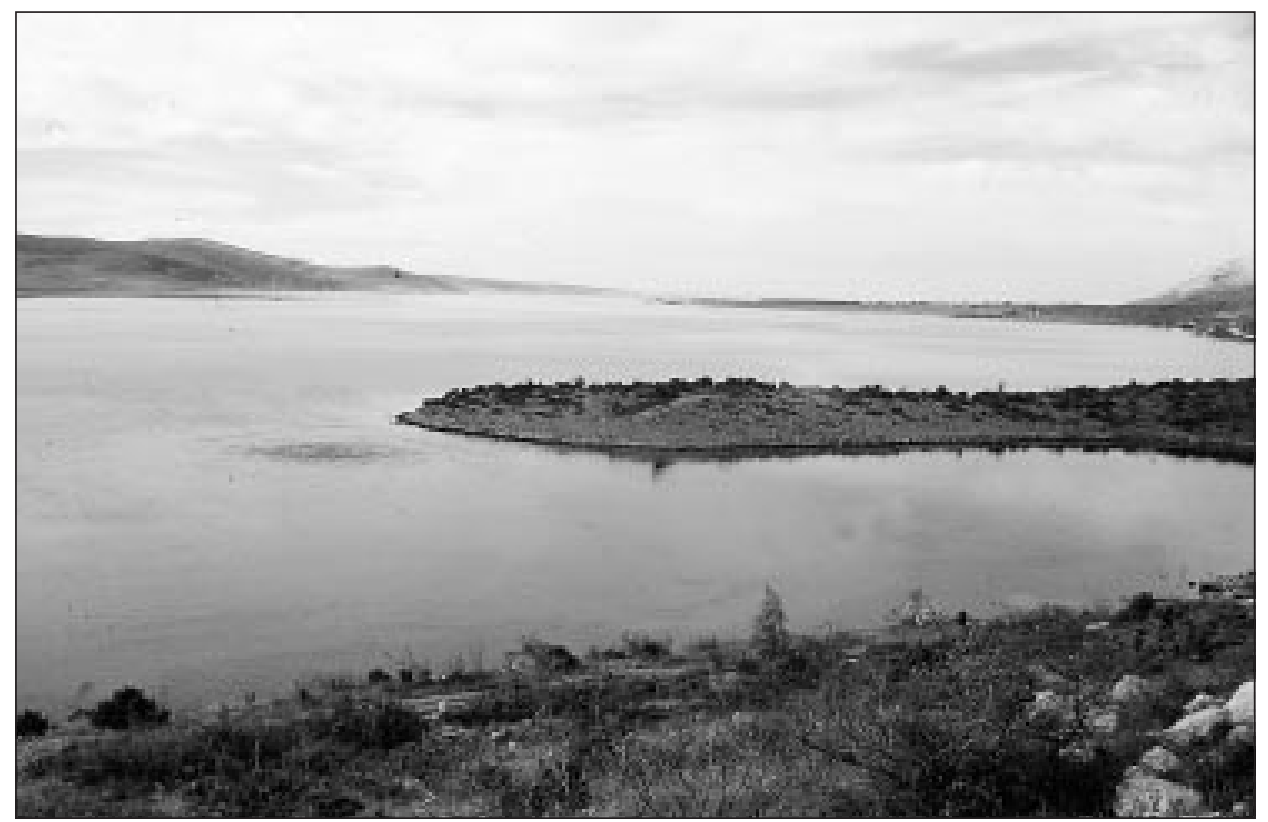

Fig. 2: Submarine spring Vrulja Zečica near Starigrad (Photo by D. Petricioli).

Although located at or above the sea level, brackish coastal karst springs, formed by sea water intrusion into the karst aquifer, can be considered as an integral part of submarine karst. The intrusion of marine influences in dense crystalline carbonate is much more irregular than in porous coral limestones, but penetration along conduits can be considerable (Ford \& Williams 1989). Intensity of marine intrusion is very variable and depends on many factors such as superficies of contact zone of the sea and karstified rock, level of karstification, connection of the fissures, orientation of major conduits, fresh water discharge, hydraulic gradient of hinterland groundwater, etc (Milanović 1979). Brackish spring Stabanj near Vrana Lake (Biograd na moru) located $10 \mathrm{~m}$ a.s.l. is influenced by the sea water percolating under the flysch "hanging" hydrogeological barrier although it's about $6 \mathrm{~km}$ far from the sea (Fritz 1992). 


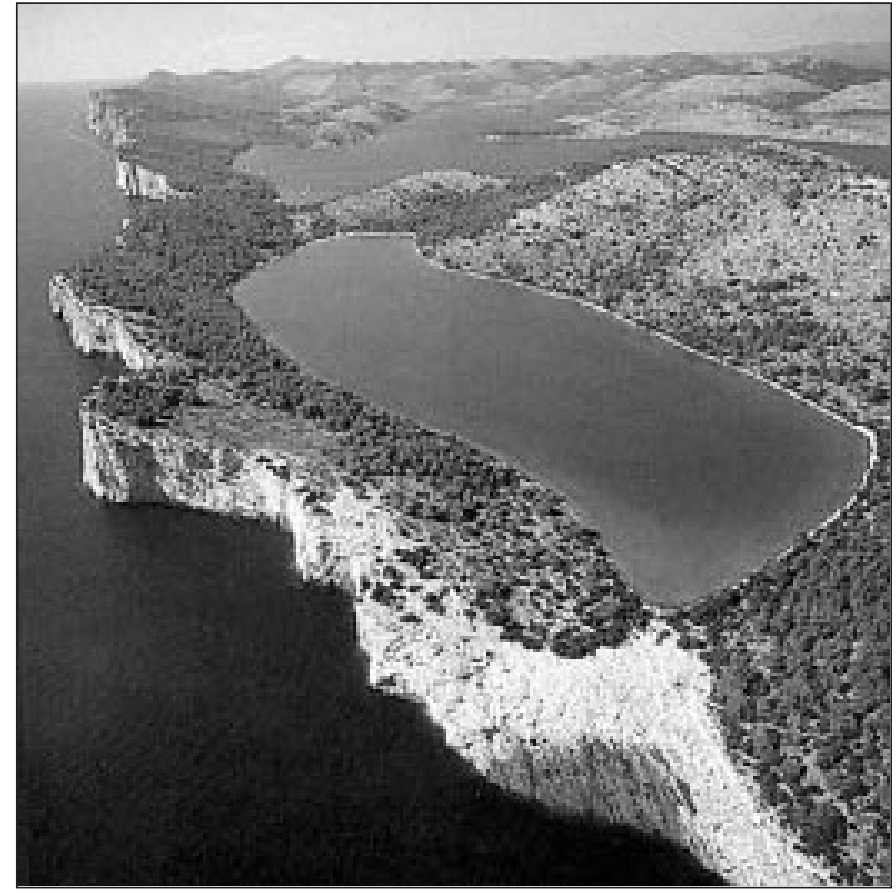

Fig. 3: Marine lake Mir (Dugi otok Island) with steep tectonical coast - fault plane of Dugi otok fault.

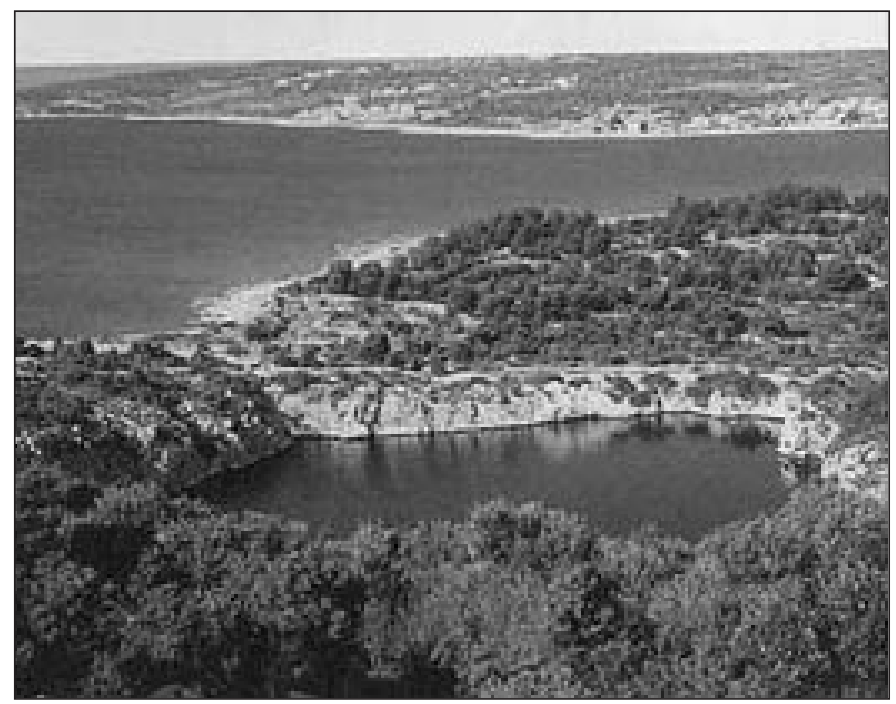

Fig. 4: Marine lake Zmajevo oko (Dragon's eye) near Rogoznica.
Even more interesting is the hydrological system near Trogir which consists of submarine springs Arbanija and Slatina in Bay of Kaštela at the depth of 32 and 35 (39) $\mathrm{m}$ respectively, the permanent brackish spring Pantan at 2,7 m a.s.l. cca $400 \mathrm{~m}$ far from the sea and intermittent brackish spring Slanac (meaning "salty") at 30 $\mathrm{m}$ a.s.l. During the lower, Late PleistoceneHolocene sea level stands, hinterland water had been discharging through the coastal springs which, after the sea level rise, became submarine springs in the Bay of Kaštela. Simultaneous groundwater rise resulted in the appearance of coastal spring Pantan on higher elevation and decreasing runoff through vruljas. They became just occasionally active throughout the rainy periods due to increased pressure in the hinterland. During the summer, decreasing pressure induces reversible process with landward sinking of salt water into the previous vruljas, acting now as marine estavelles, and directing sea water through passages devel- 
oped by former fresh water activity (Herak 1972; Fritz 1981, 1992, 1994). Therefore, the salinity of water in the underground and on Pantan outlet significantly increases. After the dry periods during which the underground is saturated with salt water, sudden water waves of high underground tides (re)activate Slanac Spring with brackish runoff. This discharge is active only for about 10 days a few times in a year, but not necessarily every year (Fritz 1992).

Besides submerged springs, submerged dolines are also common features on the Eastern Adriatic sea bottom. Transition forms from subaerial to submarine dolines are quite common on Mljet Island (Bognar \& Curić 1995), and are also on some other Croatian islands (Silba, Olib). They appear as the shallow depressions near coastline, at or below the sea level. The bottoms filled with impermeable residuum (terra rossa) retain the rain-water and create muddy ponds (blatine). Nevertheless, the water is in most cases slightly brackish, not only because of windborne sea drops, but because of the underground sea water penetration (Bognar \& Curic 1995).

Similar in origin, but much more impressive are marine lakes. There are four such features in Croatia: Lake Mir (Fig. 3), Lake Zmajevo oko (Dragon's eye) (Fig. 4) and lakes Malo Jezero (Small Lake) and Veliko jezero (Large Lake) on the island of Mljet. Marine lake Mir, located on the SW side of Dugi otok island, is 5,8 m deep with the dimensions of 910 × $280 \mathrm{~m}\left(0,23 \mathrm{~km}^{2}\right)$ (Prostorni plan 1990).

Zmajevo oko is situated on the Gradina Peninsula near Rogoznica; its maximum depth is 15 $\mathrm{m}$ and dimensions are $150 \times 70 \mathrm{~m}\left(5300 \mathrm{~m}^{2}\right)$ (Bakran-Petricioli \& Petricioli 1997). Lake Veliko Jezero, located at the NW side of the island of Mljet, consists of three basins $\left(1,45 \mathrm{~km}^{2}\right)$ with maximum depth of $46 \mathrm{~m}$. It is connected with the open sea by a 2,5 m deep channel (Soline) and the connection to $29 \mathrm{~m}$ deep Malo jezero $\left(0,24 \mathrm{~km}^{2}\right)$ is via an artificial channel less than $1 \mathrm{~m}$ deep (Wunsam et al. 1999).

The genesis of all these lakes was the same at the very beginning - bottoms of karst depressions were partly submerged by the underground water that was rising simultaneously with the sea level rise. Freshwater lake sediments are found under the brackish and marine sediments at the bottom of the Mljet island's lakes (Juračić et al. 1995; Wunsam et al. 1999; Govorčin et al. 2001), whereas at Zmajevo oko and Mir lakes, such investigations still have not been conducted, but one can expect similar situations. However, further sea rise caused penetration of the sea water through the karstified limestones. Since the lakes Mir and Zmajevo oko are, in fact, collapse dolines, nowadays they exist in a form of lakes, whereas Malo Jezero and Veliko Jezero, which are semi-enclosed depressions (Bajraktarević et al. 2000; Govorčin et al. 2001), became sea bays at the time the sea level reached the channels' heights. Apparently, Malo jezero existed as a lake somewhat longer than Veliko Jezero because of the shallower channel.

Evident sea level oscillations within lakes Mir and Zmajevo oko (here even smoother daily oscillations), indicate their indirect connection with the open sea through, as it seems, very karstified bedrock, although the separating (bordering) mass of rock is $90-100 \mathrm{~m}$ thick. Moreover, dimensions and connections of the fractures are sufficient even for colonizing of numerous marine organisms species presently living within the lakes (Bakran-Petricioli \& Petricioli 1997).

Submarine speleological objects are also irrefutable proof of former lower sea level stands, especially speleothems within them. Caves can be formed in the marine environment by abrasion but not as complex as by underground water circulation. For example, partly submerged cave Modra Spilja (Blue Cave) on the Biševo island is originally a continental feature where abrasion just reshaped or/and opened (presently submerged) entrances (Božičević 1991) (Fig. 5). But the 


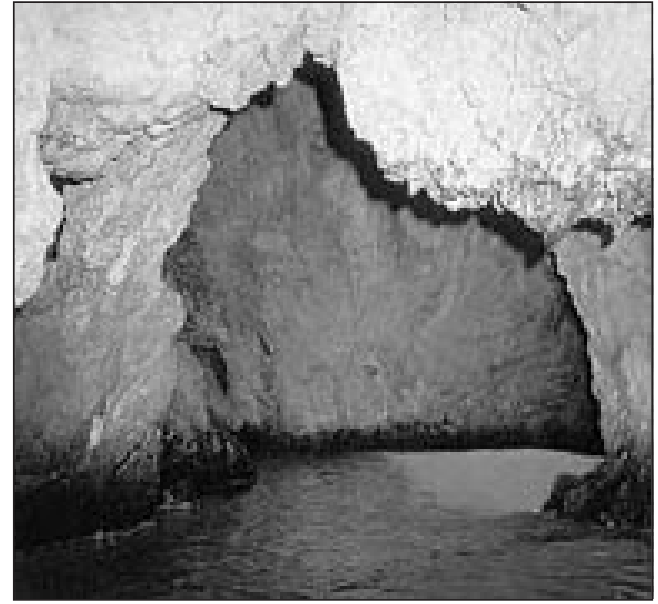

Fig. 5: Partly submerged cave Modra spilja (Blue Cave) on Biševo Island.

pits' formation is connected strictly to the subaerial conditions. There are dozens of known submerged speleological objects along the Eastern Adriatic coast: near Rovinj, Sv. Juraj, Lukovo Šugarje, Jablanac, Prizna, Starigrad, Rovanjska, Rogoznica, Brela, as well as along the islands of Lošinj, Pag, Molat, Galiola Islet nearby Ist Island, near Dugi otok, Šćedro, Hvar, Brač, Korčula, Mljet, Lastovo, Biševo Island etc. In correlation to the land, the number of uninvestigated submarine caves and pits is probably several times higher.

Speleothems inside such objects, which are, by their origins, typical subaerial features were recently the object of investigations on Late Pleistocene - Holocene sea level rise. Although for that purpose horizontal objects are more adequate because of immediate submerging of the speleothem by the rising sea, dating of speleothems from vertical objects on steep terrains also provided acceptable results. Namely, on steep terrains (present sea bottom), the bedrock between the rising sea and the pit was not so thick as to prevent sufficient sea water intrusion and establishment of the marine environment inside the objects, such as on the flatten terrains. In the Cave in Tihovac Bay (Pag Island), marine conditions with colonies of organisms belonging to characteristic biocenosis of completely dark caves and passages, at the depth of $23 \mathrm{~m}$, were probably established 8300 years ago when the distance between the cave and open sea was approximately $160 \mathrm{~m}$. In the Pit in Lučice Bay (Brač Island), at depths of 36 and 34 $\mathrm{m}$ such conditions were established c. 10500 and 9100 y BP respectively, when the open sea was less than $170 \mathrm{~m}$ far from the pit (Surić 2002).

These presumptions are supported by above mentioned present situations of the marine lakes Zmajevo oko and Mir with evident sea level oscillations and living marine organisms.

\section{CONCLUSIONS}

Submerging of the karst by the sea water does not completely nullify various processes characteristic for karst landforms. Moreover, erosion occur ring within submarine springs and hydrology can be even more complex than on the land. Due to the type of secondary permeability, the rate and mode of sea water landward penetration is variable and the mixing does not occur uniformly (Herak 1972). Sporadically, rate of karstification is high enough for establishing not only brackish, but the real marine environment within the coastal speleological objects and depressions. Of course, such a concept should not be taken as a general. In fact, every locality requires individual approach according to specific geological, geomorphological and hydrogeological settings. 


\section{REFERENCES}

Alfirević, S., 1969: Jadranske vrulje u vodnom režimu Dinarskog promorskog krša i njihova problematika, Carsus Iugoslaviae, 6, JAZU, 183-205, Zagreb.

Bajraktarević, Z., Ćosović, V., Vaniček, V. \& Juračić, M., 2000: Raznovrsnost bentičkih foraminiferskih zajednica s odabranih lokaliteta mljetskih jezera, $2^{\text {nd }}$ Croatian Geological Congress, Proceedings, 77-81, Zagreb.

Bakran-Petricioli, T. \& Petricioli, D., 1997: Ekološke osobitosti morskog jezera Zmajevo oko kraj Rogoznice, Povid - zbornik radova o primoštenskom i rogozničkom kraju, Županijski muzej, Šibenik, 75-82.

Bakran-Petricioli, T. \& Petricioli, D., 1999: Život u moru - Podvelebitske vrulje, Ekološki glasnik, 4, 17-23, Donja Lomnica.

Benac, Ц C., 1989: Morfogeneza vrlo strmih i okomitih obala na području Kvarnera, Pomorski zbornik, 27, 485-495, Rijeka.

Bognar, A. \& Zámbó, L., 1992: Some new data of the loess genessis on Susak island, Proceedings of the international symposium "Geomorphology and Sea”, Mali Lošinj, 1992., Zagreb.

Bognar, A., Klein, V., Mesić, I., Culiberg, M., Bogunović, M., Sarkotić-Šlat, M. \& Horvatinčić, N., 1992: Quarternary sands at south-eastern part of the Mljet island, Proceedings of the international symposium "Geomorphology and Sea", Mali Lošinj, 1992., Zagreb.

Bognar, A. \& Curić, L., 1995: Geomorfološke značajke otoka Mljeta, In: Durbešić, P. \& Benović, A. (ed): Mljet. Proceedings of Symposium "Prirodne značajke i društvena valorizacija otoka Mljeta", Ekološke monografije, 6, 107-116. Zagreb.

Bognar, A. \& Grizelj, M., 1996: Geomorfološke značajke arhipelaga Kornata, Proceedings of Symposium Kornati - Prirodna podloga, zaštita, društveno i gospodarsko valoriziranje, Ekološke monografije, 7, 53-66, Zagreb.

Božičević, S. 1991: Fenomen krš, Školska knjiga, p. 104, Zagreb.

Correggiari, A., Roveri, M. \& Trincardi, F., 1996: Late Pleistocene and Holocene Evolution of the North Adriatic Sea, Il Quaternario, 9 (2), 697-704.

Fairbanks, R. G., 1989: A 17000-year glacio-eustatic sea level record: influence of glacial melting rates on the Younger Dryas event and deep-ocean circulation, Nature, 342, 637-642.

Ford, D.C., Williams, P., 1989: Karst Geomorphology and Hydrology, Chapman \& Hall, p. 601, London.

Fritz, F., 1981: Hidrogeologija zaleđa Splita, Carsus Iugoslaviae, 10, JAZU, 97-118, Zagreb.

Fritz, F., 1992: Effect of recent sea level change on development of karst phenomena, Proceedings of the international symposium "Geomorphology and Sea", Mali Lošinj, 1992., Zagreb.

Fritz, F., 1994: On the appearance of a brackish spring $30 \mathrm{~m}$ above sea level near Trogir (Southern Croatia), Geologia Croatica, 47/2, 215-220, Zagreb.

Fritz, F. \& Bahun, S., 1997: The morphogenesis of submarine springs in the Bay of Kaštela, Croatia, Geologia Croatica, 50/1, 105-110, Zagreb.

Govorčin, D. P., Juračić, M., Horvatinčić, N. \& Onofri, V., 2001: Holocene sedimentation in the Soline Channel (Mljet lakes, Adriatic Sea), Natura Croatica, Vol. 10, No 4, 247-258, Zagreb.

Herak, M., 1972: Karst of Yugoslavia, in: Karst - Important Karst Regions of the Northern Hemisphere, ed. M. Herak \& V. T. Stringfield, Elsevier, p. 531, Amsterdam.

Horvatinčić, N. Čalić, R. \& Geyh, M. A., 2000: Interglacial Growth of Tufa in Croatia, Quaternary Research, 53, 185-195. 
Juračić, M., Sondi, I., Barišić, D., Vdović, N. \& Pravdić, V., 1995: Sedimenti i sedimentacija u mljetskim jezerima (Hrvatska). In: Durbešić, P. \& Benović, A. (ed): Mljet. Proceedings of Symposium "Prirodne značajke i društvena valorizacija otoka Mljeta", Ekološke monografije, 6, 107-116. Zagreb.

Kennett, J. P., 1982: Marine Geology, Prentice-Hall, Inc., p. 752, New Jersey.

Magaš, D., Faričić, J. \& Surić M., 2001: Elafitsko otočje - fizičko-geografska obilježja u funkciji društveno-gospodarskog razvitka, Geoadria, 6, 31-55, Zadar.

Milanović, P. T.,1979: Hidrogeologija karsta i metode istraživanja, HE “Trebišnjica”, Institut za korištenje i zaštitu voda na kršu, p. 302, Trebinje.

Prostorni plan područja Parka prirode Telašćica - Osnove plana, 1990, ed.: Damir Magaš, Zavod za urbanizam - Zadar, p. 180, Zadar.

Roglić, J., 1967: Prilog poznavanju reljefa jadranskog priobalskog dna, Rad JAZU, 345, 39-54, Zagreb.

Surić, M., 2002: Gornjopleistocensko-holocensko kolebanje morske razine na istočnoj obali Jadrana, M. Sc. thesis, Faculty of Science, p. 102, Zagreb.

Wunsam, S., Schmidt, R. \& Müller, J., 1999: Holocene lake development of two Dalmatian lagoons (Malo and Veliko Jezero, Isle of Mljet) in respect to changes in Adriatic sea level and climate, Paleogeography, Paleoclimatology, Paleoecology, 146, 251-281.

\section{PODMORSKI KRAS NA HRVAŠKEM - DOKAZ O NEKDANJI NIŽJI MORSKI GLADINI}

\section{Povzetek}

Velik del hrvaškega dinarskega krasa je danes pod morjem, kot posledica zgornje pleistocenske - holocenske transgresije. Pred približno 18000 leti, v času največje würmske poledenitve, je bila morska gladina okoli $125 \pm 5$ m nižja od današnje. Tako je bila karbonatna kamninska osnova podvržena zakrasevanju do absolutne baze, do morske gladine. Ker porečja rek na vzhodni jadranski obali sestavljajo pretežno lahko topne karbonatne kamnine in zato odlagajo zelo malo sedimentov, je pod morsko gladino še vedno mogoče prepoznati večino kraških oblik, kot so škraplje, vrtače, jame, brezna, rečne soteske, itd.

Zaradi dviga morske gladine so se obalni izviri spremenili v podmorske - vrulje. Sočasno so se zaradi dviga morske gladine pojavili obalni izviri z zapletenimi hidrološkimi posebnostmi v večjih višinah. Najbolj zanimiv je hidrološki sestav blizu Trogira, ki ga sestavljata podmorska izvira Arbanija in Slatina v Kaštelanskem zalivu, stalni zaslanjeni izvir Pantan 2,7 m n.m. in zaslanjena zaganjalka Slanac 30 m n.m. Zaradi vdora slane vode v manjše vrtače na kopnem so nastale številna zaslanjene lokve (»blatine«), posebno številne na otokih Mljetu, Silbi in Olibu, medtem ko večje udornice predstavljajo morska jezera: Mir na Dugem otoku, Zmajevo oko pri Rogoznici ter Veliko in Malo jezero na Mljetu. Opazno nihanje morske gladine v jezerih Mir in Zmajevo oko kaže na njuno neposredno povezanost z odprtim morjem, najbrž skozi zelo zakraselo matično kamnino. Še več, velikost razpok in njihova povezanost z morjem je celo tolikšna, da so jezera naselili morski organizmi. Ugotavljanje, kdaj je morje zalilo kapnike v potopljenih jamskih objektih (jama v zalivu Tihovac na Pagu, brezno v zalivu Lučice na Braču) tudi kaže na vpliv morja skozi relativno debelo gmoto zakrasele matične kamnine v zgodnjih fazah potapljanja. 